\title{
Recent Developments in German Antarctic Research
}

1

Hempel, G., Prof. Dr., Director of Alfred Wegener Institute for Polar Research, Columbus Center, D-2850 Bremerhaven, FR Germany

\section{Introductory Summary}

In recent years polar research in the Federal Republic of Germany has been developed rather rapidly with very substantial support by the government. Major features of this support are the establishment of the Alfred Wegener Institute for Polar Research in Bremerhaven in 1980, the construction of the overwintering ice shelf station "Georg von Neumayer" off Queen Maud Land, Antarctica in 1981, 2 srimmer huts in North Victoria Land in 1981 and 1983, anc summer station at the edge of the Filchner Ice Shelf in the innermost Weddell Sea at 770S, 500 W in 1982, and finally the commissioning of the ice breaking research and supply vessel RV "Polarstern" in late 1982.

The scientific community of the Federal Republic of Germany has compiled a catalogue of projects of polar research which various groups want to carry out at universities and research institutions, partly in collaboration with the Alfred Wegener Institute which has the responsibility of overall coordination and logistic support of the polar programme. The German Research Council (DFG) as the major national funding agency of academic research has a priority programme in support of those projects.

Areas of special interest are

The Pacific margin of the east Antarctic continent, particularly the northern edges of Weddell Sea (Schwabenland) and Ross Sea (North Victoria Land).

- The geological history of Weddell Sea and northern parts of Norwegian Sea.

Budget of the Filchner Ice Shelf, its past and present movements.

- Paleoclimate as documented in ice cores and marine rediments.
- Air-ice-sea interaction in the ice shelf and in the pack-ice zones of Weddell Sea, Norwegian Sea and Arctic Ocean.

- Climatic effects of variations in the ice cover.

- Formation of Antarctic bottom water in Weddell Sea.

- Exchange of water masses and fauna through Fram Strait connecting Arctic Basin and Norwegian Sea.

- Interhemispheric transport in ocean and atmosphere using natural and man made tracers.

- The marine Antarctic ecosystem with emphasis on the lower parts of the food chain and on biology of krill.

- Comparisons of Antarctic and Arctic marine communities.

- Metabolic adaptations of polar plants and animals.

- Technology of shipping and drilling in ice.

Most emphasis is given to multidisciplinary projects involving scientists of various institutions. Presently, research in the Antarctic is dominating, there is, however, a growing interest in Arctic studies, too.

In the following text we will select some of the technical and scientific aspects of the new German programme and put it into an historical perspective as well as into the framework of international cooperation in polar research.

\section{Historical Background}

Polar navigation by German explorers and naturalists started under British and Russian flag in the 18th and early 19 th centuries. The first period of German expeditions to the Arctic began in the 1860 s with cruises by K. Koldewey to Greenland and Spitsbergen waters. Geographical and navigational explorations were carried out by German and 
Austrian vessels. The Arctic work was mainly initiated by A. Petermonn. Since then geomorphology, glaciology, meteorology, geology and biology of the Arctic and Subarctic islands have been fields of German research activities. A. Wegener's Greenland expeditions are outstanding examples. In the Polar Years 1882/83 and 1932/33 as well as in the International Geophysical Year (IGY) 1958/59, observations were established in the Arctic. In the Polar Front Survey of the International Geographical Year and the Overflow Project on the Iceland-Faroe Ridge research vessels of several countries cooperated for the first time according to a strict scheme of transects and observations. Both programmes had been partly initiated by G. Dietrich.

In the Antorctic the early exploration of the Southern Ocean, its islands and coasts has first been carried out mainly through the great British and French expeditions of the 18th century followed by the sealers and explorers of various countries, foremost British and American in the 1820s. The third phase of Antarctic exploration started around 1860 and was of a more scientific nature. Between 1873 and 1883 five German vessels sailed south mainly for the exploration of the waters, islands and seal stocks off the Antarctic Peninsula. To a limited extend, oceanography and biology were also studied together with astronomical and geophysical observations. More important was the scientific work in connection with the establishment of observatories on Kerguelen Is. and South Georgia for the study of the transit of Venus in 1874 resp. 1882. The studies were of broad scale, covering not only astronomy, geomagnetics, meteorology and observations of auroras but also geographical and biological descriptions of South Georgia. In addition a detailed account was given of the flood wave caused by the eruption of Mt. Krakatau in August 1883.

During the "heroic phase" of Antarctic research at the beginning of the 20th century German research was confined to two major sea-going expeditions by RV "Gauss" in 1901-03 under E. von Drygalski to the East-Antarctic and by RV "Deutschland" in 1911-13 under W. Filchner. For the "Gauss"-Expedition the US Antarctic Gazetteer states "much scientific observation but little exploration accomplished". In terms of published results in meteorology and geophysics but also in oceanography and in biological sampling the "Gauss"-Expedition was even more successful than the "Deutschland"-Expeditions. However, the oceanographic observations during the long drift of the vessel in the pack-ice of the Weddell Sea are up to now one of the few complete sets of winter data in this area.

$G$. von Neumayer has been the promotor of German Antarctic research for more than 30 years at the end of the last century. Together with $K$. Weyprecht he was one of the key figures for the First International Polar Year 1882/83 and for the development of international cooperation in Antarctic research. On his advice Germany did not engage in the attempt to reach the South Pole, but to carry out multidiscliplinary work in the Southern Ocean and on the coasts and islands of Antarctica. This strategy was largely continued during further periods of German Antarctic research since World War I:

- The "Schwabenland"-Expedition under H. Ritscher in 1938/39 to Queen Maud Land where the first photogrammetric survey of a large area of Antarctica was carried out together with marine biological studies.

- Since 1975, a number of biological and geological/geophysical expeditions to the Weddell Sea/Scotia Sea and to the Ross Sea and its coasts (Tab 1), leading amongst others to the establishment of the overwintering station "Georg von Neumayer" at Atka Ice Port and summer stations at Filchner Ice Shelf and in North Victoria Land.

\section{The New Start}

The recent development of German Antarctic research followed several lines in parallel to the expeditions listed in Tab 1:

the entering of the scientific and political fora of Antarctic nations,

- the development of a national programme for polar research particularly in the Antarctic,

- the establishment of two Antarctic research stations, the construction of an ice breaking research and supply vessel, and

- the foundation of a national institute of polar research.

\section{The Political Sphere}

The geological and biological expeditions have resulted in more and closer contacts of the West-German scientific community with the working groups of SCAR (Scientific Committee on Antarctic Research). The results of the first two krill expeditions by "Walther Herwig" became important elements for the development of the international programme BIOMASS as the major cooperative study in marine research under the flags of SCAR and SCOR (Scientific Committee on Oceanic Research). Biologists of the Institute of Marine Science, Kiel and of the Federal Institution for Fisheries Research in Hamburg were actively engaged in the design and coordination of BIOMASS, particularly its first field phase FIBEX in 1980. The biological and oceanographic data collected by 14 research vessels in FIBEX are being analyzed jointly by all participants at a data center in Hamburg. In 1978, the German Research Council joint SCAR.

During the International Geophysical Year, there was no independent German expedition to the Antarctic nor was an Antarctic station established. German scientists, however, participated in many expeditions and overwinterings of other countries. In particular, representatives 
Tab 1 Antarctic expeditions by the Federal Republic of Germany 1975/76 - 1982/83

\begin{tabular}{|c|c|c|c|c|}
\hline $\begin{array}{l}\text { Year } \\
\text { (Antarctic } \\
\text { Summer of) }\end{array}$ & Vessel & $\begin{array}{l}\text { Scientific } \\
\text { Coordinator(s) }\end{array}$ & Area & Disciplines \\
\hline $1975 / 76$ & $\begin{array}{l}\text { Walther Herwig } \\
\text { Weser }\end{array}$ & $\begin{array}{l}\text { Hempel, Sahrhage } \\
\text { Schreiber, Steinberg }\end{array}$ & Scotia Sea & $\begin{array}{l}\text { mar. biology, fisheries, } \\
\text { oceanography }\end{array}$ \\
\hline $1977 / 78$ & $\begin{array}{l}\text { Walther Herwig } \\
\text { Julius Fock }\end{array}$ & $\begin{array}{l}\text { Hempel, Sahrhage } \\
\text { Schreiber, Steinberg }\end{array}$ & Scotia Sea & $\begin{array}{l}\text { mar. biology, fisheries, } \\
\text { oceanography }\end{array}$ \\
\hline $1977 / 78$ & Explora & Hinz & Weddell Sea & mar. geophysics \\
\hline $1979 / 80$ & Schepelsturm & Tessensohn & North Victoria Land & $\begin{array}{l}\text { GANOVEX-I } \\
\text { geology, geophysics }\end{array}$ \\
\hline $1 . / 80$ & Polarsirkel & Kohnen & Filchner Ice Shelf & site survey for Ant. station \\
\hline $1979 / 80$ & Explora & $\operatorname{Hinz}$ & Ross Sea & mar. geophysics \\
\hline $1980 / 31$ & Meteor & Zeitschel, Gerlach, Hempel & Scotia Sea & $\begin{array}{l}\text { mar. biology, mar. geology, } \\
\text { oceanography }\end{array}$ \\
\hline $1980 / 81$ & Walther Herwig & Hempel, Stein, Kock & Scotia Sea & $\begin{array}{l}\text { mar. biology, fisheries, } \\
\text { oceanography (FIBEX) }\end{array}$ \\
\hline $1980 / 81$ & $\begin{array}{l}\text { Polarsirkel } \\
\text { Gotland II, Titan }\end{array}$ & Kohnen & $\begin{array}{l}\text { Atka Bay, } \\
\text { Weddell Sea }\end{array}$ & $\begin{array}{l}\text { installation of Georg-von-Neu- } \\
\text { mayer-Station, mar. biology }\end{array}$ \\
\hline $1981 / 82$ & Gotland II & Tessensohn & North Victoria Land & $\begin{array}{l}\text { GANOVEX-II } \\
\text { geology, geophysics }\end{array}$ \\
\hline $1981 / 82$ & John Biscoe & Heywood, Hempel & Scotia Sea & $\begin{array}{l}\text { mar. biology, oceanography } \\
\text { (a joint UK/FRG expedition) }\end{array}$ \\
\hline $1981 / 82$ & Polarqueen & Gravenhorst & $\begin{array}{l}\text { Atka Bay } \\
\text { Weddell Sea }\end{array}$ & $\begin{array}{l}\text { installation of Filchner summer } \\
\text { station, glaciology, chemistry }\end{array}$ \\
\hline $1982 / 83$ & Polarstern & Hempel & Weddell Sea & $\begin{array}{l}\text { ANTARKTIS-I, meteorology, } \\
\text { oceanography, mar. biology, } \\
\text { mar. geology, ice technology }\end{array}$ \\
\hline $198 ? / 83$ & Polarbjörn & Kohnen & Weddell Sea, Kraul Mts. & geological land expedition \\
\hline $120+183$ & Polarqueen & Tessensohn & North Victoria Land & $\begin{array}{l}\text { GANOVEX-III } \\
\text { geology, geophysics }\end{array}$ \\
\hline
\end{tabular}

of geophysical sciences in the German Democratic Republic have since 1960 established a long tradition of close cooperation with the Soviet Antarctic Expeditions almost from their commencement. West-German scientists were participants in programmes of the United States of America, the United Kingdom, France and other countries. But it was not before 1979 that the Federal Republic of Germany signed the Antarctic Treaty, and reached consultative status in 1981. The German Democratic Republic had signed the Treaty in 1974 already. German scientists participated in the consultations for the Convention on the Conservation of Antarctic Marine Living Resources and for a convention on the exploration and exploitation of mineral resources in the Antarctic. These consultations resulted in an increasing awareness both by the government and by the general public for the need for more polar research, particularly in the Antarctic. This has supported the scientific community to develop an ambitious research programme. In December 1979 the Bundestag (parliament) decided unanimously in favour of a substantial governmental engagement in Antarctic research.

\section{Instruments for Polar Research}

Polar Institute. Continuity in polar research requires a permanent organizationa! structure for coordination, financing and logistics, either through a national institute (as in the United Kingdom and the USSR) or through a scientific committee plus funding agency (USA, South Africa). The German Research Council (DFG) recommended the first alternative.

The Alfred Wegener Institute for Polar Research which was established in 1980 in Bremerhaven, has at present a scientific staff of 42 scientists and assistants. A doubling is envisaged within the next five years. Part of the staff is employed on a temporary basis, mainly postgraduates and 
postdocs for short-term projects. Long-term objectives are geophysics and meteorology in the observatory, ecology and sedimentology of the Weddell and Scotia Seas, the protection of nature, pollution research, meteorology and oceanography of the ice edge and pack-ice, and the dynamics of the Filchner Ice Shelf. The Alfred Wegener Institute coordinates national polar research within the framework of international cooperation. Its own research is intimately linked with universities which are sponsored by the German Research Council under a special priority programme for Antarctic research.

The Polar Institute cooperates closely with the Federal Research Institutes for Fisheries, and for Geosciences and Mineral Resources. In the international sphere, particularly close cooperation was already established with British and Polish scientists. The national SCAR committee advises on national programmes and international cooperation.

The Alfred Wegener Institute is also responsible for logistic support of national programmes. In the first two years it chartered vessels and helicopters. By the end of 1983 hopefully two twin engine airplanes (Do 128 and Do 228) will be made available, one of them equipped for geophysical, meteorological and photogrammetrical surveys for land and snow operations. Various vehicles and cranes are based at the Georg-von-Neumayer-Station.

The Georg-von-Neumayer-Station (GvN) was set up in February 1981 in Atka Bay, at 70037'S 08022'W. Besides a technical crew (doctor, mechanic, radio operator, cook), two meteorologists and one geophysicist participate in the overwintering in 1983. For meteorology and aerology of the Ekstrom Ice Shelf GvN runs a complex meteorological observatory. The geophysical observatories for registration of seismic activity of the ice shelf and earth crust, for gravimetry, and for magnetometry as well as the air chemistry lab are separated from the main station by $1000 \mathrm{~m}$ because of possible disturbances by the station itself. GvN is also used as a base for geological, geophysical, geodetic and glaciological campaigns during the Antarctic summer. In summer, 28 persons can work at the station.

Furthermore, the glaciologists will study the dynamics of the ice shelves. For this purpose, the Filchner Summer Station was set up in February 1982, at about $20 \mathrm{~km}$ from the edge of the Filchner Ice Shelf, at 77009'S 50039' W. Instead of using tubes for housing as at GvN, in Filchner containers were installed which are put on stalks. The Filchner station will serve as base for a programme to investigate the mass budget of the Filchner Ice Shelf, and for geological-geophysical investigations around the Weddell Sea. It is planned to install automatic instrumentation for year round recordings of geophysical and meteorological data.

RV "Polarstern", built in 1981/82, is $118 \mathrm{~m}$ long and $25 \mathrm{~m}$ wide. With $20,000 \mathrm{HP}$, she is able to operate continuously in ice of about $1.5 \mathrm{~m}$ of thickness. This extends the seasonal and geographical range of action in polar waters and allows to study the living conditions of plank. ton and krill in the pack-ice zone, and the interaction of ice, ocean and atmosphere. The ship is equipped for collecting long sediment cores and for fishing with commerciat trawls. To study the morphology of the ocean-bottom, "Polarstern" uses SEABEAM.

RV "Polarstern" carries both, installed laboratories and transportable container-labs. She can carry 4,000 tons of supply goods, including fuel and containers. To unload heavy vehicles and containers on sea-ice or on the edge of the ice shelf, the vessel has special cranes with wide operational range carrying 10 and 25 tons. There are $41 \mathrm{crew}$ members on board; a further 30 passengers for summer expeditions, maintaining the stations and for overwintering can be carried together with 35 scientists working on board the ship.

The vessel will operate for approximately 80 days a year in the Arctic and for 180 days in the Antarctic. On its way to and from the operational areas, oceanographers, air chemists and geomorphologists will use the ship for trans. atlantic sections. One to two months each year will be reserved for dock and harbour time. The operational plan is determined by the Polar Institute in agreement with interested working parties of other institutes, and in taking in to account international projects. The Institute encourages participation of foreign scientists in the cruises of RV "Polarstern".

\section{Major Lines of Research}

In 1978/79 the German Research Council (DFG) through its national SCAR committee compiled a catalogue of about 90 major Antarctic research projects which have been suggested by scientists of various institutes. The list consisted of projects covering all fields of natural science, from upper atmosphere physics to microbiology.

In a long series of round table discussions which involved in total about 300 scientists the research projects were weighted by their scientific value, technical feasibility and financial implications.

Within three years out of the original catalogue of projects a number of topics emerged which seem to become the focal points of the Antarctic research programme for the 1980s. Within the programme priority of funding and logistic support is given to cooperative national and international projects which involve more than one discipline and/or groups of scientists of different institutions. Only those projects were included which refer directly to genuine Antarctic problems, or are related to global problems which can most effectively be studied in polar regions.

In geosciences major emphasis is given to the western margin of the old continent of eastern Antarctica. The geological and geophysical work has started with expeditions to the northernmost ends of it around the eastern and 
southern Weddell Sea (Schwabenland) and to the entrance of Ross Sea (Victoria Land). Both, the history of the break up of Gondwana and the formation of the south western Pacific are the central problems behind those studies which involve geology and geophysics both on the continent and in the sea bed, particularly in the southern Weddell Sea along the Filchner Ice Shelf. The recent geological history of the Weddell Sea as documented by its sediments is related to the general problem of the history of glaciation in both hemispheres. Sedimentological studies similar to those in the Weddell Sea are planned for the northernmost part of the Norwegian Sea.

a study of the paleoclimate has already started by analysis of marine sediments and of ice and snow cores. They are related to a large-scale project on the ice budget of the Filchner ice Shelf as one of the most important outlets of the Antarctic ice cap. This very question together with the related problems of meteorology were the reasons for placing a German station at the Filchner Ice Shelf.

Research has been started on the movement of the Filchner Ice Shelf, its structure and dynamics together with the major forces in the current system and in atmosphere, the flux of energy and matter between ice shelf and atmosphere above and sea water underneath the floating ice mass. Work will be intensified during a series of multidis ciplinary summer campaigns. A grid by $500 \mathrm{~km}$ will be worked on in cooperation of various disciplines such as glaciology, geodesy, geophysics and meteorology.

The general problem of air-ice-sea interaction will be studied in the pack-ice zones of Weddell Sea and Norwegian Se? Treenland waters and Fram Strait and in the Arctic Oceall. The first Antarctic expedition by RV "Polarstern" in January-March 1983 was partly devoted to these problems. "Polarstern" will also participate in the international Marginal Ice Zone Experiment (MIZEX) which will start in eastern Greenland waters in 1983. The effects of large-scale variations of pack-ice cover on climate are poorly understood. Numerical models making also use of satellite monitoring of ice cover and sea surface temperature will be needed. They have to be based on data from direct measurements both in South and North polar waters.

In oceanography the near surface movements related to air-ice-sea interaction and transport of pack-ice is not the only field of special interest to German polar sciences. The formation of the Antarctic bottom water in the Weddell Sea and the dynamics of water masses at the edge and underneath the ice shelf are further problems on which work has just started. The transport of deep water masses is being monitored at the deepest entrance from the Weddell Sea into the Scotia Sea and from there to Argentine Basin. in Arctic waters the exchange of water masses and their fauna between the Arctic Basin and Norwegian Sea through Fram Strait will be a major problem to be studied by physical and biological oceanographers.
On an even larger scale is the inter hemispheric transport of heat and of air and water masses. Modern analytic technology permits quantitative estimates of natural and man-made chemical tracers as means for measuring the meridional flow. Snow and ice preserve most of those tracers and will indicate variations in inter-hemispheric transport. Comparative studies in various parts of the globe are needed. Detailed knowledge of the ratio between the tracer content of the air and in sea water and snow is required for calibration purposes. Year round monitoring of gases like Radon and Krypton as well as a regular sampling of snow at the Georg-von-Neumayer-Station for further analysis go parallel to seagoing observations of tracers in atmosphere and sea water in the Southern Ocean and on ocean-going transects between Europe and Antarctica.

In biology emphasis is on the Southern Ocean ecosystem in comparison to the communities in northern waters. Four aspects seem of particular interest: the conditions under which phytoplankton patches develop and disappear, which are the staple food of krill and other herbivores/omnivores. Microbiology of polar waters is also little understood and deserves more attention in any study of the lower parts of the Antarctic food web. Very little is known in quantitative terms about life in winter and in the pack-ice zone. The diatoms in sea ice are of particular interest. RV "Polarstern" is specially built for studies under heavy ice conditions.

There is a great difference in the plankton communities of the Westwind drift and the Eastwind drift including the Weddell Sea gyre. Similarities between the Westwind drift plankton and the communities in the Norwegian Sea are obvious, good comparisons between Eastwind drift and Arctic Basin are still scarce. The reasons for the predominance of krill in the Eastwind drift are not known, nor the reasons for the scarcity of krill in the inner Weddell Sea.

Results on biology and physiology of krill as obtained during the expeditions of RV "Walther Herwig" and RV "Meteor", shall be augmented by direct studies of krill swarms in the area of the Weddell-Scotia confluence between South Orkney Is. and South Shetland Is. in a combination of direct observations, net sampling and oceanography. In general work on large oceanic fronts has a long tradition in German physical and biological oceanography since the Polar Front Survey of IGY. A special study area for marine biologists and fishery scientists will be around Elephant 1. west of South Shetland Is., where krill and fish as well as their major predators (pinguins and seals) are abundant. The Filchner Trough in the south eastern corner of Weddell Sea is a further area of interest to oceanography, biology and geology.

Physiological adaptations in polar organisms have often been studied. However, major contributions can still be expected from experiments on the biochemical background of metabolic adaptations to low temperatures. For 
this purpose RV "Polarstern" is fitted with container laboratories for culture experiments, microbiology, biochemistry and radio-isotope experiments with marine organisms. For studies on adaptations in terrestrial plants and animals German biologists are largely depending on work in foreign stations.

For engineering science the construction of the Georgvon-Neumayer-Station as a dug-in tube system and of Filchner Summer Station as the traditional elevated container complex provided good opportunities for research in construction on ice. Development of ice ankers and drilling devices are further topics of the engineering programme. RV "Polarstern" is in itself an instrument for technological research. The vessel has already been used for observations on the structure and breaking properties of sea ice of different origin and structure.

\section{International Cooperation}

Polar research has always been a matter of national pride and of international cooperation. Since the first Polar Year German scientists were active in promoting the idea of integrated international projects. As mentioned above the development of BIOMASS was of great importance to the formation of the Antarctic marine biological work in FR Germany. Other projects by SCAR in various fields are supported by observations of German expeditions and in particular at Georg-von-Neumayer-Station. An international programme for the study of the Filchner ice budget is under preparation which will involve a major contribution by the Alfred Wegener Institute and various German universities. During the past decades many German scientists enjoyed the hospitality of foreign polar vessels, research stations and institutes. Time has now come that foreign researchers may work on RV "Polarstern" and at the Georg-von-Neumayer-Station, as they already do in the Alfred Wegener Institute.

\section{Conclusions}

Recent development in polar research in the Federal Republic of Germany has a focus on the Antarctic region, although Arctic studies are gaining weight in the marine field and in some terrestrial projects.

The emphasis on marine problems seems justified on scientific grounds, it follows the tradition of German polar research and is determined by the provision of an icebreaking research vessel with facilities to work in the vast but still rather unknown areas of the pack-ice zone. In addition, geophysical work combining studies at sea and on land and on ice, observations at the Georg-von-NeumayerStation and major terrestrial projects like GANOVEX and Filchner Ice Budget play a considerable role in the overalt programme.

Experience over the next few years may demonstrate how far this young programme will bear fruit in form of scientific results and in the development of close scientific cooperation on a national and international level. 